\title{
DIAGNOSING AND DEVELOPING THE E-BUSINESS COMPETENCIES OF THE "Z" GENERATION
}

\author{
DIAGNOSTYKA I ROZWÓJ KOMPETENCJI E-BIZNESU POKOLENIA „Z”
}

https://doi.org/10.34739/zn.2019.49.01

Katarzyna Czainska

Poland, SGH Warsaw School of Economics, Collegium of Business Administration ORCID: 0000-0001-5863-8638, e-mail: kczain@sgh.waw.pl

\begin{abstract}
The purpose of the article is to present an example of a diagnostic tool for identifying the competence gap of representatives of the " $Z$ " generation who want to conduct business in the e-business model. The first part presents the characteristics of the "Z" generation (Gen-Z) based on studies of Polish and foreign literature. Groups of individual professional competences important for e-business owners were also identified, which were developed on the basis of the results of personal research carried out in 2018 by the CAWI method. The methodological part presents the construction and application of the "e_BIS" tool, which can be used to diagnose the current state and development of competences, broken down into competences: business (B), IT (I) and strategic leadership (S). Based on preliminary analyses, it was formulated that the presented tool can be useful both in education (secondary and higher) and on the labour market to properly shape the individual professional competences of representatives of the "Z" generation.
\end{abstract}

Keywords: "Z" generation (Gen-Z), e-business competencies, individual professional competencies

\begin{abstract}
Streszczenie: Celem artykułu jest zaprezentowanie przykładowego narzędzia diagnostycznego służącego do identyfikacji luki kompetencyjnej przedstawicieli pokolenia Z, którzy chcą prowadzić działalność gospodarczą w modelu e-biznesu. W pierwszej części przedstawiono charakterystykę pokolenia Z sporządzoną na podstawie studiów literatury polskiej i zagranicznej. Wskazano także grupy indywidualnych kompetencji zawodowych ważnych dla właścicieli e-biznesu, które opracowano na podstawie wyników badania własnego zrealizowanego w 2018 roku metodą CAWI. W części metodologicznej zaprezentowano budowę i zastosowanie narzędzia "e_BIS", za pomocą którego można diagnozować stan obecny oraz rozwój kompetencji, w podziale na kompetencje: biznesowe (B), informatyczne (I) oraz przywództwa strategicznego (S). Na podstawie wstępnych analiz sformułowano założenie, że prezentowane narzędzie może być użyteczne zarówno w szkolnictwie (średnim i wyższym) oraz na rynku pracy, by właściwie kształtować indywidualne kompetencje zawodowe przedstawicieli pokolenia Z.
\end{abstract}

Słowa kluczowe: pokolenie Z, kompetencje e-biznesowe, indywidualne kompetencje zawodowe

\section{Introduction}

The subject of analysis of this article are the e-business competences of the "Z" generation (Gen-Z). In a very broad context, it can be stated that this is a group belonging to a society heading to the information society model. The word "heading to" was used deliberately to emphasize the evolutionary nature of the change, which was already noted in the 1950s and named in the 1960s (in 1963 by Tadao Umesamo and in 1968 by Kenichi Koyama) (GobanKlas, Sienkiewicz, 1999, 42). In the modern world there is not yet a country whose society could be described as fully informative, i.e. those that, according to the adopted definition, not only has developed means of information processing and communication, but information processing is the basis for creating national income and provides a livelihood for the majority of society (Goban-Klas, Sienkiewicz, 1999, 53). In addition to the above concept, the assumption formulated in 2004 by Isazadeh was recognized; in a simple sentence he has stated that the information society is based on the flow of information and knowledge, therefore it is: global in principle, open, transparent, governed by knowledge and competence, and a new game with a whole new set of rules (Isazadeh, 2004). Young people from the "Z" generation subconsciously know this game and participate in it. Older generations are still learning and / or shaping it. Therefore, as stated 
above, there may not yet be an information society, but there is already a generation prepared and expecting to live in such a society and, above all, work there.

This article presents the results of a study whose purpose was to characterize the ' $Z$ ' generation in terms of professional competences and to check whether these competences correspond to the needs of the e-business market. A broad understanding of the concept of e-business was adopted, which included: electronic commerce (ecommerce), electronic enterprises (e-enterprise), and electronic government / administration (egovernment) (Nojszewski, 2004). The article also presents the "e_BIS" tool, which can be used to diagnose the current state and development of competences, broken down into business (B), IT (I) and strategic leadership (S) competences.

\section{Features of the " $Z$ " generation on the labour market vs. e-business competences - literature review}

The " $Z$ " generation is the youngest scientifically defined generation of people who are starting to enter the labour market or have been functioning on it for some time. These are people who were born after 1995. In order to identify the characteristics of this generation on the labour market, the following restrictions were adopted: (1) the analysis was narrowed to people born in the years 1995 - 2003, because they can realistically function on the current labour market in Poland (due to the age entitling them to work); (2) in order to avoid duplication of research results announced by various authors, the selection of sources focused on publications that presented a review of the literature on this issue. The result of the analysis is presented in a synthetic form in Table 1. The above analysis shows that in most publications, as the special features of the " $Z$ " generation, the authors mentioned: (a) focusing on development; (b) high expectation from employer / manager; Bateh underlined however, that they do not prefer any particular style of leadership (Bateh, 2018); (c) self-confidence; (d) natural switching between virtual and real world; (e) virtual communication; authors identified that, opposite to Millenials, they want to be more anonymous; attention should also be paid to the very important fact concerning the communication of this generation, namely the maximum reduction of content; people of the " $Z$ " generation are used to very concise and general information, orders, commands, do not use sophisticated courtesy forms and often unconsciously shorten the distance to the recipient of the message.

It is also worth critically approaching the above research results and noting that they create the impression of contradictory; for example, it was identified that people from the " $Z$ " generation: (1) expect an interesting job, but are quickly bored; (2) declare their willingness to develop, but they have no patience to learn; it is possible that they expect more immediate response to the problem at the moment rather than well-established knowledge; (3) comment and express opinions on the internet, preferring to remain anonymous, and at the same time commonly run blogs, videos and post photos from private life on social media; for many it is the preferred career path and / or consciously shaped personal branding (Sidor-Rządkowska, 2016).

The question then arises whether this contradiction is the result of: (a) methodological errors of the research itself; (b) actual contradiction in the characteristics of the "Z" generation; (c) interpretative errors and even overinterpretation. In addition, it is worth to consider why, despite so many positive features indicated, it was within this generation group, that the NEET subgroup was separated, in which there is a phenomenon of lack of involvement in two main areas of social life, namely education and work. Based on the results of conducted research, it was noticed that young people from the NEET subgroup rate their competences in the use of the Internet the highest (but they use it mostly for entertainment and spending free time), and the lowest level of their professional qualifications (Wiśniewska, Wiśniewski, Szydło, 2019). 
Table 1. Features of the "Z" generation from the perspective of the labour market

\begin{tabular}{|c|c|c|c|c|c|c|}
\hline \multirow[b]{2}{*}{ Most of " $Z$ " generation representatives: } & \multicolumn{6}{|c|}{ Authors } \\
\hline & $\begin{array}{l}\text { Torocsik, } \\
\text { Szucs, } \\
\text { Kehl } \\
(2014) \\
\end{array}$ & $\begin{array}{c}\text { Williams } \\
\text { (2015) }\end{array}$ & $\begin{array}{l}\text { Lyons, } \\
\text { Lavelle, } \\
\text { Smith } \\
(2017) \\
\end{array}$ & $\begin{array}{c}\text { Dolot } \\
(2018)\end{array}$ & $\begin{array}{l}\text { Fratricova, } \\
\text { Kirchmayer } \\
\quad(2018)\end{array}$ & $\begin{array}{l}\text { Bateh } \\
(2018)\end{array}$ \\
\hline 1. are creative & & & $X$ & & & \\
\hline $\begin{array}{l}\text { 2. are focused on development (willing } \\
\text { to accomplish new levels of knowledge } \\
\text { acquisition) }\end{array}$ & $\mathbf{x}$ & & $\mathbf{X}$ & $\mathbf{x}$ & $\mathbf{X}$ & \\
\hline $\begin{array}{l}\text { 3. would like to achieve a spectacular } \\
\text { professional career immediately, without } \\
\text { any effort }\end{array}$ & $\mathrm{X}$ & & $\mathrm{X}$ & $\mathrm{X}$ & & \\
\hline $\begin{array}{l}\text { 4. have high expectation from employer / } \\
\text { manager (leadership skills and } \\
\text { knowledge) }\end{array}$ & & & $\mathbf{X}$ & $\mathbf{x}$ & $\mathbf{X}$ & $\mathbf{x}$ \\
\hline 5. want to finish a college or university & $\mathrm{X}$ & & $\mathrm{X}$ & & & \\
\hline 6. have knowledge of foreign languages & & & $\mathrm{X}$ & $\mathrm{X}$ & & \\
\hline 7. are self-confident & & $\mathbf{X}$ & $\mathbf{X}$ & $\mathbf{X}$ & $\mathbf{X}$ & \\
\hline 8. are disloyal to the employer & & & $\mathrm{X}$ & & & \\
\hline 9. are individual / independent & & & $\mathrm{X}$ & & $\mathrm{X}$ & \\
\hline 10. have team work problems & & & $\mathrm{X}$ & & & \\
\hline $\begin{array}{l}\text { 11. have knowledge of computer programmes } \\
\text { supporting professional tasks }\end{array}$ & & $\mathrm{X}$ & $\mathrm{x}$ & $\mathrm{X}$ & & \\
\hline 12. prefer telework & & & $X$ & & & \\
\hline $\begin{array}{l}\text { 13. accept and expect changes; do not care } \\
\text { about stability at work }\end{array}$ & & & & $X$ & $X$ & \\
\hline $\begin{array}{l}\text { 14. switch between virtual and real world, } \\
\text { they perceive them as complementary } \\
\text { to one another }\end{array}$ & $\mathbf{x}$ & $\mathbf{X}$ & & $\mathbf{X}$ & & $\mathbf{x}$ \\
\hline $\begin{array}{l}\text { 15. source and check the information they } \\
\text { need in the internet }\end{array}$ & & $\mathrm{X}$ & & $x$ & & $\mathrm{X}$ \\
\hline $\begin{array}{l}\text { 16. quickly share information or manifest } \\
\text { opinions mostly via variety of } \\
\text { communication devices or social media } \\
\text { (embrace anonymous one) }\end{array}$ & $\mathbf{x}$ & $\mathbf{X}$ & & $\mathbf{X}$ & & $\mathbf{x}$ \\
\hline 17. due to applications support multitasking & & & & $\mathrm{X}$ & & \\
\hline $\begin{array}{l}\text { 18. look for a job not only in their closest } \\
\text { surroundings, but all over the world } \\
\text { (mobility) }\end{array}$ & & & & $x$ & & \\
\hline $\begin{array}{l}\text { 19. consider self-employment (mostly } \\
\text { freelancing) as a way of professional activity, } \\
\text { especially because they consider it as better } \\
\text { paid and as giving a sense of independence }\end{array}$ & $\mathrm{x}$ & & & $\mathrm{X}$ & $\mathrm{X}$ & \\
\hline 20. private happiness & $x$ & & & & $\mathrm{X}$ & \\
\hline 21. work of interest & & & & & $\mathrm{X}$ & \\
\hline 22. lose interest very fast & & $\mathrm{X}$ & & & & \\
\hline 23. take care of their personal brand / image & $\mathrm{X}$ & $\mathrm{X}$ & & & & \\
\hline $\begin{array}{l}\text { 24. trust young people from their own generation } \\
\text { who have achieved something significant } \\
\text { in a field, or at least they are famous }\end{array}$ & $\mathrm{X}$ & & & & & \\
\hline
\end{tabular}

Nevertheless, the information contained in the subject literature is important for theoreticians and practitioners who deal with the labour market, management and related fields. It was observed, among others, that work in e-business, especially in the form of personal business activity, creates conditions in which most of the expectations of representatives of the "Z" generation can be fulfilled. In order to verify this thesis, the characteristics of the examined generation were compared with the competences required in the e-business model. Competences are divided into four categories (knowledge, skills, predispositions / attitudes and experiences) corresponding to the definition of 
individual professional competences (Table 2); it was assumed that individual competences consist of: knowledge, experience, predispositions and attitudes of a given person, and the individual's professional competences are part of his individual competences (Juchnowicz, 2014; Spencer, Spencer, 1993); besides, it was assumed that individual competences can be shaped in relation to specific requirements, e.g. the labour market or a given profession, or depending on the preferences and expectations of a given person; individual professional competences should be shaped depending on the requirements of the labour market, organization strategy and the specificity of a given job (Rostkowski, 2012).

It is also important to distinguish between "business in the e-business model" and "earning from being present in the virtual world". The second solution applies to all forms of individual promotion of a person / persons in social media, e.g. by posting videos and photos, running blogs and video blogs, commenting on content published in the media. This solution is not the main subject of this article. Some information, however, may also be useful in the above activities.

Table 2. Individual professional competences of the "Z" generation*

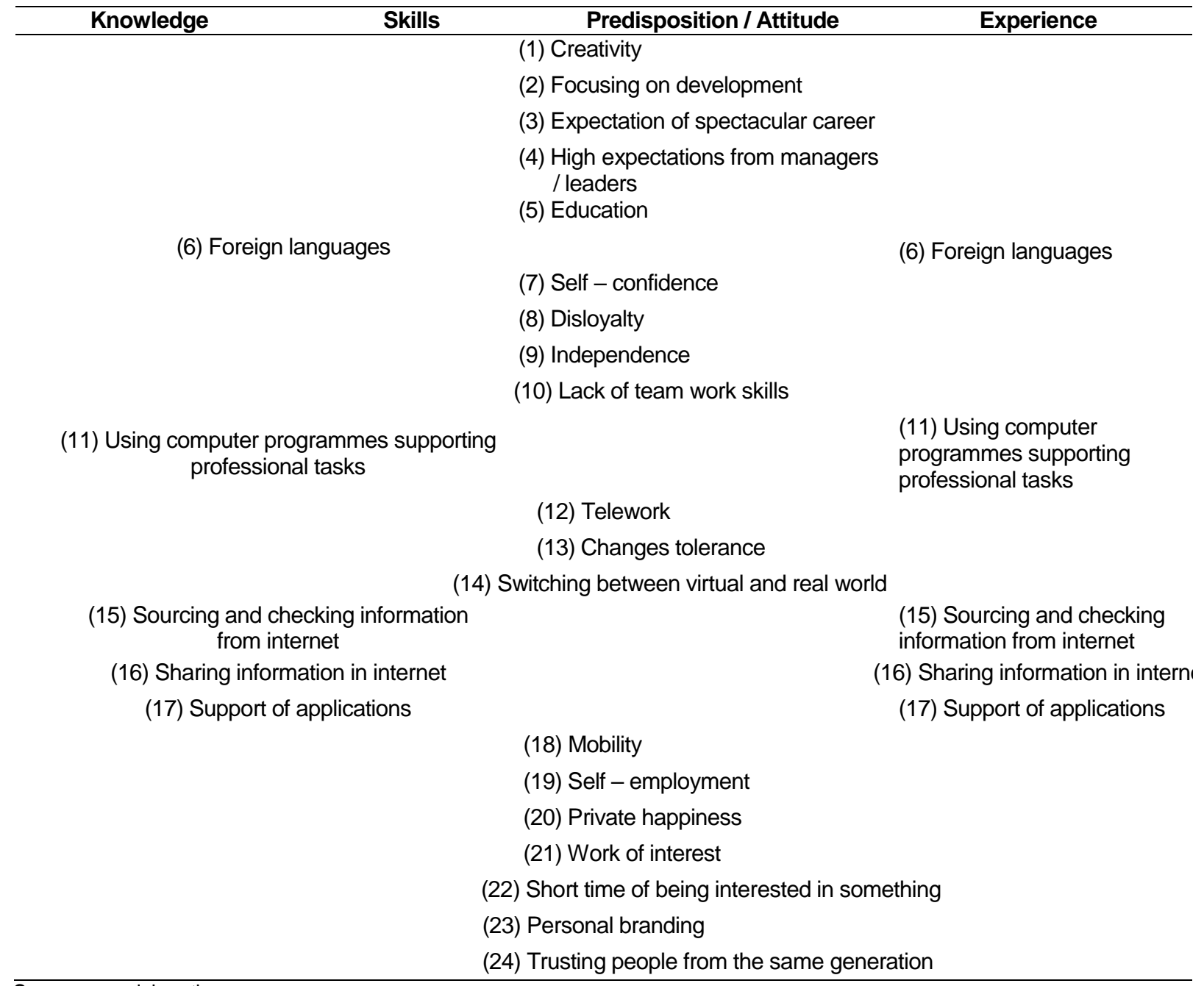

\footnotetext{
Source: own elaboration
}

* The statements have been simplified; the numbers in brackets indicate the equivalent in Table 1.

The list of e-business competences was developed on the basis of the results of personal research conducted since 2017. In the first stage of this work, an initial pool of 38 statements was made regarding individual e-business competences. The following research reports were used: (1)
Przywództwo w organizacji 2017 [Leadership in organization 2017] (SGH, 2017); (2) Raport Gumtree. Aktywni+. Przyszłość rynku pracy [Gumtree report. Active +. The future of the labour market] (Gumtree, 2017). In order to confirm the accuracy of selected competences, in February 2018 
a preliminary test using the CAWI (ComputerAssisted Web Interview) method was conducted. Access to the online survey with questionnaires on the internet was sent to respondents, including employees of the e-business sector (e-commerce and e-commerce support companies) and to young people who could potentially develop their business in the e-business sector. The respondents' task was to indicate which competencies are necessary in e-business. 44 questionnaires eligible for the study were received. The results of the study confirmed the significance of selected competences, however, it should be remembered that the study was verifying, not cognitive, and therefore the data analysis was not the basis for changing the list of competences. The correctness of reading meanings by the respondents and the hierarchy of competences indicated were important. As a result of the study, three categories of competences were identified: (1) business - B, (2) information technology - I, (3) strategic leadership - S (Table 3).

Table 3. List of top-rated e-business competences in the initial verification test

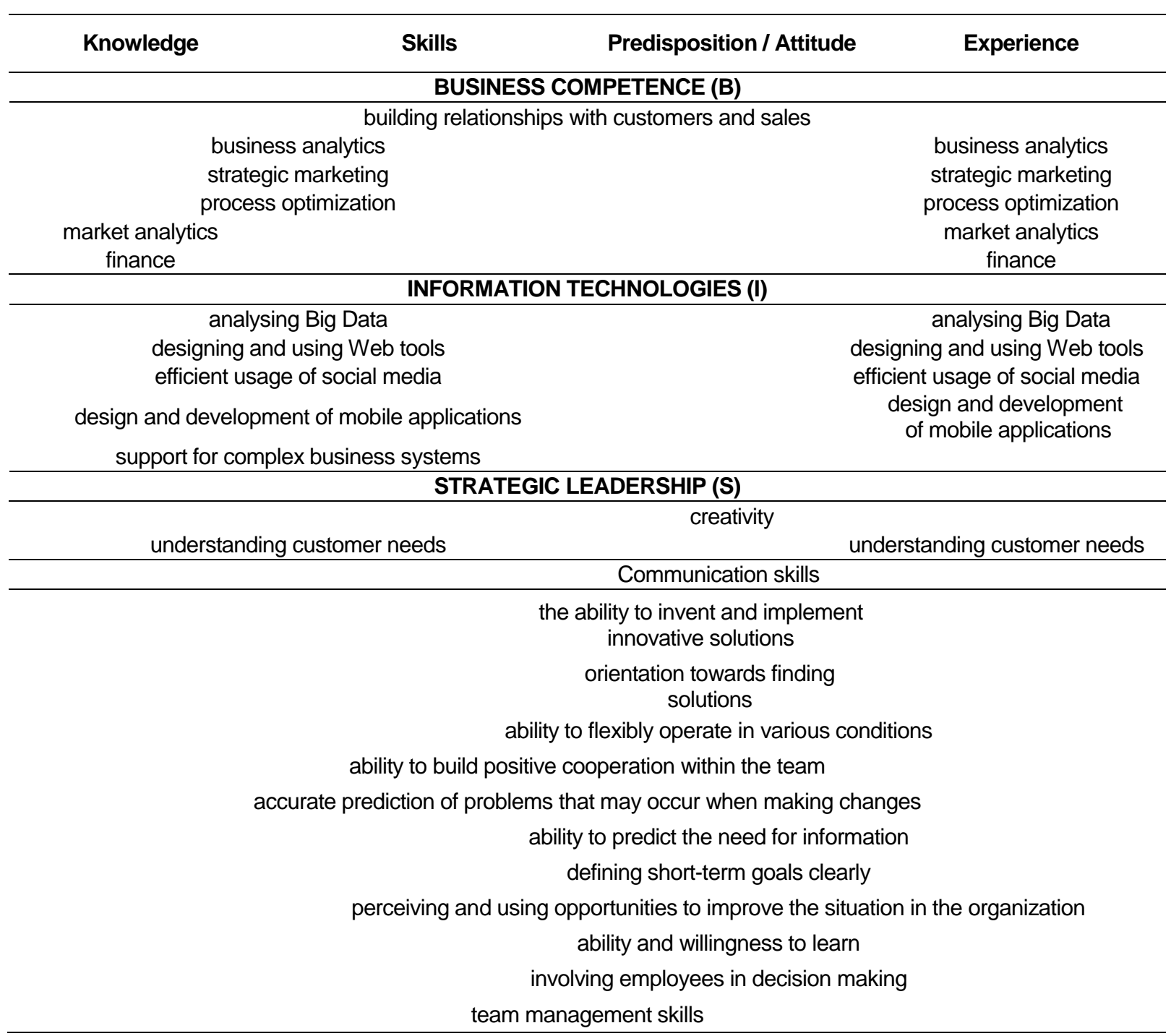

Source: own elaboration

Particular attention was paid to the fact that work in e-business has the hallmarks of working in virtual teams, therefore, when considering the problem of diagnosing and managing competences, the following are also taken into account: (a) substantive competences (knowledge and skills in the discipline concerned by e-business); (b) work and management competences; (c) competences related to the organization of one's own work; (d) virtual social competences; (e) cognitive skills; (f) digital competences; (g) the ability to overcome barriers resulting from the use of online communication; $(\mathrm{h})$ competence in the field of network behaviour (Krawczyk - Bryłka, 2017; Czupryna- 
-Nowak, 2017; Fryczyńska, 2017). A common feature of e-business employees is also a constant desire to improve. This is due to the high dynamics of technological and market changes in the sector, forcing such an attitude among these people (Kazak, 2017).

\section{Methodology and theoretical basis}

In order to improve the process of diagnosing competences, the "e_BIS" application project was developed. This tool is available in the form of a spreadsheet that allows to conduct a Computer Assisted Interviewing (CAI) technique, including in particular: 1/ Computer Assisted Personal Interviewing (CAPI) - interviewing by an interviewer using a computer; 2/ Computer Assisted Self Interviewing (CASI) - by making the computer (laptop) available to the respondent who independently completes the questionnaire without the interviewer's interference. The survey can also be carried out using the Paper and Pen Personal Interviewing (PAPI) technique by completing the paper version of the survey; however, this is a labourintensive solution, as it will require the interviewer to enter data into the system in order to receive results. Ultimately, the survey is to be a Computerized SelfAdministered Questionnaires (CSAQ) solution, available in the following techniques: (a) Mobile Computerized Self-Administered Questionnaires (MCSAQ), where the computerized questionnaire will be completed by respondents using mobile devices; b) Computer-Assisted Web Interview (CAWI), where respondents access the questionnaire using a web browser. The adoption of such a solution will be in line with modern research standards, resulting from the need to take into account: a) time limits on both the respondents and interviewers; (b) mentality and preferences of the young generation of respondents (entrepreneurs) who prefer "electronic" communication channels.

The tool consists of a respondent module and an analytical module, available only to the consultant / adviser. The first module includes sheets with diagnostic questionnaires, results presentation sheets and training programme presentation sheets. The analytical module is used for mathematical and logical processing of data in accordance with the formulas introduced; the exception is the "General training programme module", which introduces a list of subjects (courses, trainings) that correspond with the diagnosed competences and form the basis for the development of the "Individual / Group Training Programme". The diagnostic tool (questionnaire) has the form of a matrix, which is commonly used in the field of testing competences and training needs (Juchnowicz, 2014; Bielińska, 2017).

The first column lists 38 items divided into three categories: (a) B - business; (b) I - Information Technology; (c) S - in the field of strategic leadership. In the following columns, the respondent assesses:

- "Current status" (CS) / "Stan obecny" (SO) - level of the given competence in the current period; the assessment is made on a scale of 0 to 5 , where 0 means no competence, and 5 - very high competence,

- "Training needs" (TN) / "Potrzeby szkoleniowe" (PS) - training needs related to a given competence; the assessment is made on a scale of 0 to 5 , where 0 means no training needs, and 5 - very high training needs,

- "Validity" (V) / "Ważność" (W) - how important a given competence in current work is for him; the assessment is made on a scale of 0 to 5 , where 0 means invalid and 5 means very important.

Based on the assessments given by the respondent, the system indicates areas requiring training divided into:

- selected by the respondent - when TN> 3;

- recommended - when (TN - CS) $>=3$;

- to be considered - when $\mathrm{CS}<\mathrm{V}$ and $\mathrm{TN}<=3$. In the first case, it is assumed that since the respondent indicates "Training need" at a level greater than 3 , then the desire to improve should be used and training should be carried out in the given scope. Recommended trainings are indicated when the difference between the "Training need" and the "Current state" of competences is greater than or equal to 3 , which means that the respondent notices the low level of current competences and at the same time has a great need to reduce the competence gap (acquiring knowledge). In the case of the third category, i.e. "to be considered", it is recommended to consult the respondent with a survey or training specialist; there is a situation in which a given competence is very important in the respondent's current work, his current competences are insufficient, and at the same time he/she does not show the desire to improve. Because there are many reasons for the above situation, it should be clarified precisely; it may turn out that the respondent uses the services / assistance of a specialist external company in a given scope (e.g. providers of solutions in the field of website management).

The system also presents an illustration of the level of competence gap and training needs in the form of a bar and radar chart (Figure 1). This does not affect the interpretation of the results, but it can 
be used when discussing and determining the scope of training, as some respondents / decision makers prefer the pictorial form.

Based on the results obtained, "e_BIS" also suggests the scope of training that will allow the development of competences and bridging the gap.
An analysis of the respondents' progress is made immediately after the training or at an agreed interval after the training. The rules for completing the questionnaire are similar to those in earlier stages. The results are also presented in tabular and graphical form.
B - Business

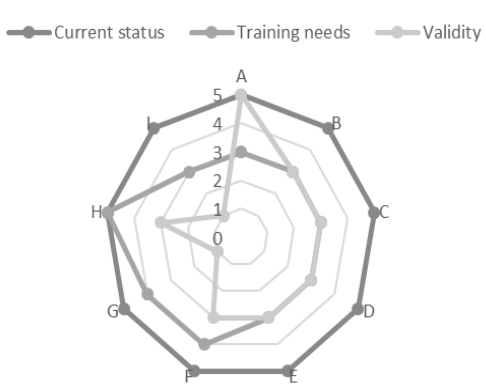

I - Information Technology

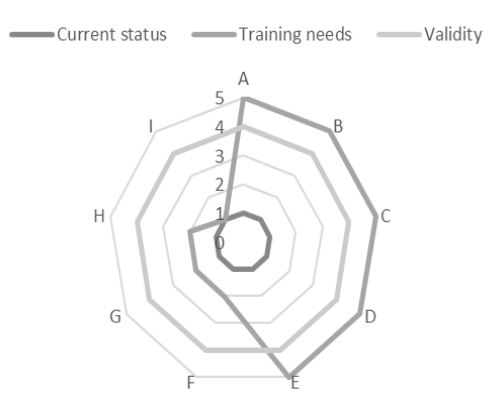

S - Strategic leadership

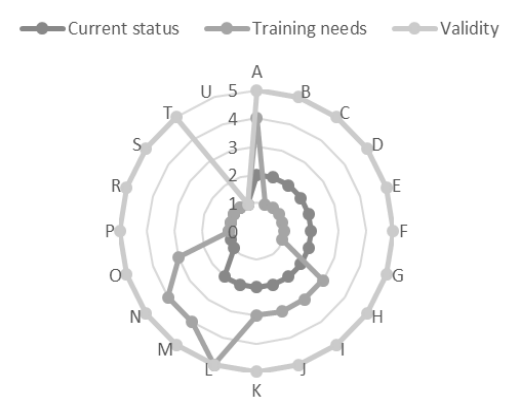

Figure 1. The level of competence gap and training needs - example

Source: own elaboration

\section{Results and discussion}

The basis for the effectiveness and utilitarianity of the described tool is primarily the correct formulation of competences to be diagnosed using it. Another important element is a properly selected training programme that responds to potential competence gaps identified in the study process. The key factor in the success of the entire competence development process is, of course, the training itself, including the form and techniques used. The advantage of "e_BIS" is its flexibility, because using this tool you can carry out both individual and group tests in multiple configurations:

a) option 1 - respondent (A) assesses their competences;

b) option 2 - the respondent $(A)$ assesses the competences of another person (B), e.g. the supervisor assesses the competences of the employee;

c) option 3 - respondent (A) assesses the competence of a group of people (C), e.g. the supervisor assesses the competence of employees;

d) option 4 - a group of respondents (C) assesses another person (A), e.g. a group of employees assesses a given employee;

e) option 5-a group of respondents (C) assesses another group of people (D), e.g. a group of trainees assesses a group of trainees;
The matrix of diagnostic options also applies to posttraining tests to determine progress.

The flexibility of the "e_BIS" tool should be considered as an asset also due to the differences in competences resulting from demographic variables; an interesting comparison would be to examine the differences in competence of representatives of age groups, or people with different seniority; in addition, research could also be subjected to the ability to acquire knowledge in specific age groups.

\section{Conclusions}

In the presented study, two sets of competences were compared: (a) professional of the " $Z$ " generation and (b) professional required in e-business. The above statement shows the following conclusions: (1) e_business is a business model covering many business activities different according to the criteria of legal form, size, scope of activity, etc.; the use of the "e_BIS" tool therefore requires some customization or even verification of the required competences, as the indicated set of competences cannot be considered complete and universal; (2) further research should be conducted into the definition of a set of common professional competences so as not to lead to a situation where the NEET subgroup is expanding, which has a sense of a competence gap in relation to the labour market; (3) systematic development of professional competences of the " $Z$ " generation at various levels 
of education should not be limited to narrow specializations (e.g. development of IT skills and skipping soft competences); (4) observations and actions aimed at bridging the gap in interpersonal competences identified in research should also be carried out at various levels of education. Furthermore, additional tests of competences used and necessary in the activity of so-called occurrence in the network; because this activity is becoming an increasingly frequent source of income for the young generation and creates a real pattern of achieving benefits without the need for professional competence.

\section{References}

Bateh, D. (2018). Leadership style from Millennials to generation Z Transformed. Conference paper. Academy of Management. https://www. researchgate.net/publication/331736235

Leadership_from_Millennials_to_Generation_Z_ Transformed.

Bielińska, N. (2017). Matryce kompetencji jako narzędzie wspomagające zarządzanie zasobami ludzkimi w przedsiębiorstwie produkcyjnym. Przedsiębiorczość i Zarządzanie, Tom XVIII, Zeszyt 3, Część II, 155-169.

Czupryna-Nowak, A. (2017). Kompetencje informatyczne pracowników przedsiębiorstw. Zeszyty Naukowe Politechniki Śląskiej, Seria: ORGANIZACJA I ZARZĄDZANIE z. 102, Nr kol. 1975, Gliwice

Dolot, A. (2018). The Characteristics of Generation Z. e-mentor nr 2 (74), 44-50.

Fratricova, J., Kirchmayer, Z. (2018). Barriers to work motivation of generation $Z$. Journal of Human Resource Management, vol. XXI, 2/2018, 28-39.

Fryczyńska, M. (2017). Zachowania sieciowe a rozwój kariery pracowników. Pomiar i zależności. Organizacja i Kierowanie Nr 3 (177).

Goban-Klas, T., Sienkiewicz, P. (1999). Społeczeństwo informacyjne: Szanse, zagrożenia, wyzwania. Kraków: Wydawnictwo Fundacji Postępu Telekomunikacji.

Gumtree (2017). Raport Gumtree. Aktywni+. Przyszłość rynku pracy. Warszawa: Gumtree, Digital Economy Lab.

Isazadeh, Ayaz. (2004). Information Society: Concepts and Definitions. WSEAS Transactions on Systems. 6.
Juchnowicz, M. (Ed.). (2014). Zarządzanie kapitałem ludzkim. Procesy - narzędzia - aplikacje. Warszawa: Polskie Wydawnictwo Ekonomiczne.

Kazak, M. (2017). Kompetencje menedżerskie we współczesnej organizacji. Journal of Modern Management Process, nr 1(2)/2017.

Krawczyk-Bryłka, B. (2017). Kompetencje członków zespołu wirtualnego. Studia i Prace WNEIZ US $\mathrm{nr}$ 48/2, Szczecin.

Lyons, M., Lavelle, K., Smith D. (2017). GEN Z Rising. Accenture.

Nojszewski, (2004). Biznes elektroniczny - czyli jaki?. e-mentor 1(3), 30-33.

Rostkowski, T. (2012). Strategiczne zarządzanie zasobami ludzkimi w administracji publicznej. Warszawa: Wolters Kluwer.

SGH (2017). Przywództwo w organizacji 2017 raport z badań statutowych. Warszawa: Szkoła Główna Handlowa w Warszawie.

Sidor-Rządkowska, M. (2016). Personal branding wyzwanie dla zarządzania kapitałem ludzkim we współczesnych organizacjach. Edukacja Ekonomistow i Menedzerow, IV-VI 2016, Vol. 40, Issue 2, 13-27.

Spencer, L.M., Spencer, S.M. (1993). Competence at work: Models for superior performance. New York: Wiley.

Torocsik, M., Szucs K., Kehl, D. (2014). How Generations Think: Research on Generation Z. Acta Universitatis Sapientiae, Communicatio, 1 (2014), 23-45.

Williams, A. (2015). Move Over, Millennials, Here Comes Generation Z. New York Times, 18.09.2015. http://www. nytimes.com/ 2015/ 09/20/fashion/move-over-millennials-herecomes-generation-z.html?_r=0.

Wiśniewska, S., Wiśniewski, K., Szydło, R. (2019). Ranking kompetencji przedstawicieli generacji NEET. Edukacja Ekonomistów i Menedżerów, nr 1 (51), I-III 2019, 181-192. 